of the Guil, a torrent discharging into the Durance, in the Department of the Hautes Alpes. Three days afterwards, on Thursday the 27 th, a severe shock was felt at Grenoble, about $100 \mathrm{~km}$. west-south-west from the Queyras valley. It lasted thirty seconds, passing in a direction from west to east. All the houses were shaken, but no injury is reported beyond the fright sustained by the inhabitants. The same night, almost at the same hour, six shocks were felt at Lyons, moving in the same direction; and commotions of a similar kind are announced from Turin and the sea-coast of Provence, at Cannes and Nice in particular.

WE regret to hear that $M$. Duprez de Lonce, the celebrated naval engineer and Member of the French Academy of Sciences, is dangerously ill, and that his life is almost despaired of.

WE regret to announce the death, at Paris, at the age of seventy-four, of M. Quet, a distinguished French mathematician, well known for his works in connection with capillarity, electricity, \&c., most of which have appeared in the Comptes Rendus of the Paris Academy of Sciences.

M. W. DE Fovvrelle has published a pamphlet on "L'Aérostat dirigeable de Meudon," in which he endeavours to show that the reports current in the French Academy respecting the experiments in question are exaggerated, though at the same time he seeks to do justice to his distinguished countryman, who has twice succeeded in proving that by means of electricity the power of resistance may be imparted to balloons. He concludes by recommending that, the electric fluids having done their part, la parole est à le vapeur.

INTERESTING researches with so-called Paradise fish (Macropus venustus) were made at the Berlin Aquarium recently. The fish is a native of China, its body, only a few centimetres long, is of the brightest hues, and its bluish-green fins are so enormously large that the fish seems almost to succumb under their weight. It is easily kept, and breeds frequently in captivity; the temperature of the water it is kept in must, however, not be allowed to sink below $20^{\circ} \mathrm{C}$.

ONE result of the recent expedition sent from Quetta under Sir Oriel Tanner to punish the inhabitants of the Zhob Valley is stated in a telegram from Calcutta to be a complete survey of the whole of that valley. It has been ascertained that the best road from the Gomul Pass to Candahar does not lie, as had been supposed, through the Zhob Valley, but through the valley of the Khwandar, and that the route is practicable for a large army.

Dr. OTto Finscr left Sydney on September to by the steamer Samoa, en route for the Phonix and Union Islands, where he intends staying for some time and making extensive ethnographical collections.

THE Bolelin of the National Academy of Sciences in Cordova, Argentine Republic (Buenos Ayres, I884), has a very long paper by Señor Ameghino on his geological and palæontological investigations in the province of Buenos Ayres. The only other paper is by Herr Doering, and deals with the sinking of artesian wells in the Argentine Republic.

THE Rev. Henry H. Higgins publishes in a separate form a paper on "Museums of Natural History," read before the Literary and Philosophical Society of Liverpool. After an experience of over a quarter of a century, during which he passed several times every wcek through museum rooms, the author calculates that out of a thousand visitors to the Liverpool Museum, ten to twenty were students, 780 interested observers, and 200 loungers.

Mr. Charles C. Sherrington, B.A. of Caius College, Cambridge, has been elected to the vacant George Henry Lewes Studentship.
THE additions to the Zoological Society's Gardens during the past week include a Macaque Monkey (Macacus cynomolgus $\$$ ) from India, presented by Mr. W. J. Bennett ; a Rhesus Monkey (Macacus rhesus) from India, presented by Mr. Samuel Levi; an Ocelot (Felis pardalis) from America, presented by Mr. H. B. Whitmarsh; two King Parrakeets (Aprosmictus scapulatus) from New South Wales, presented by Mr. E. Meek ; a Cheer Pheasant (Phasianus wallichii $\$$ ) from North India, presented by Mr. E. Buck; a Pig-tailed Monkey (Musacus nemestrinus of) from Java, deposited; a Rufous-necked Weaver Bird (Hyphantornis textor) from West Africa, received in exchange; four Longfronted Gerbilles (Gerbillus longifrons), born in the Gardens.

\section{THE ROYAL SOCIETY ANNIVERSARY}

THIS meeting took place on Monday last, the time-honoured date-St. Andrew's Day-falling on Sunday. In the regretted absence of the President, Prof. Huxley, who, the Fellows were rejoiced to learn, is rapidly recovering his health from his sojourn in Italy, the Treasurer, Mr. John Evans, occupied the chair and read the following address:-

The absence of our President from his post to-day must of necessity cast a certain amount of gloom over the proceedings at this our anniversary meeting, and, personally, I feel additional regret that it devolves upon me, as your Senior VicePresident and Treasurer, to be the unworthy occupant of the chair on the present occasion. My regret at the absence of the President is, however, in one respect tempered by a strong hope, in which I am sure that you will all fervently join, that the timely retirement from arduous work which has been enforced upon him by his medical advisers may produce those beneficial results which we all so cordially desire, and that we may ere long again see among us our accomplished and valued President in renewed health and strength.

I must, however, turn from the expression of our hopes for the future, to that of our regrets for the past, and for a short time dwell upon the mournful list of vacancies which the everactive hand of death has caused in our ranks during the past twelve months. In one respect only can a topic of consolation be found in this list. It is that in extent it is less than that of last year, the total number of our deceased Fellows being only eighteen on the home list and two on the foreign list, while those numbers were twenty-one and two respectively at our last anniversary.

Both the foreign members whose loss we have on the present occasion to deplore were men of the highest distinction in chemical science. Both were residents at Paris, and both had Chairs in the French Academy, of which the one had been since I 868 one of the permanent secretaries. I cannot dwell upon the discoveries and the remarkable career of M. Jean Baptiste André Dumas, whose energy and perspicuity, even when past the limit of fourscore years, all those who of late have had the opportunity of being present at a meeting of the French Academy must have found reason to admire. An appreciative memoir of him by one of our own Fellows, who of all men living is perhaps the best qualified to judge of the value of his labours-Prof. Hofman-written while Dumas was still among us, will he found in the pages of our own Proceedings (vol. xxxviii. x.), and those of NATURE (vol. xxi. February 6, 1880). It will give some slight idea of the extent of time over which the labours of $M$. Dumas have extended if I mention that, so long ago as in 1843 , he received the Copley Medal at our hands, at a time when his chemical and physiological researches had already extended over a period of twenty-two years. M. Dumas died at Cannes on April II last, and among the most touching of the speeches at his obsequies was that of $M$. Wuirtz, whose own decease took place on the 12 th of the following month.

Although nearly twenty years younger than M. Dumas, M. Karl Adolph Würtz had for a long time been one of the most distinguished leaders of modern chemical science, especially in the department of organic chemistry, aud his merits were recognised by this Society in 1864 , when he was elected one of our foreign members, and again in 1881 , when the Copley Medal was awarded to him.

Among our English Fellows was a contemporary of Wiirtz, who, like him, had been a pupil of the illustrious Liebig, but whose bent was more on the practical than on the theoretical 
side of chemistry-I mean Dr. Angus Smith, whose official labours in favour of pure air and pure water combined both tact and zeal, and were productive of highly beneficial results.

One other chemist has been taken from among us, Mr. Menry Watts, the well-known editor of the "Dictionary of Chemistry," and of more than one issue of "Fownes's Manual."

Our other losses extend over various departments of science. In botany our ranks are thinned by the death of Dr. John Hutton Balfour, formerly Professor of Botany at Glasgow and the Emeritus Professor of that Chair in the University of Edinburgh; and of the veteran Mr. George Bentham, who had nearly completed his eighty-fourth year. During his long and varied experiences of life, botany was his constant pursuit and study; and some thirty years ago, after presenting his fine collections and library to the Royal Gardens at Kew, he devoted himself to labouring there on the Floras of Hong Kong and Australia, and in conjunction with Sir Joseph Hooker, on the "Genera Plantarum," until his health gave way in the spring of last year. The exceptional value of his botanical work was recognised by this Society in 1859 , when a Royal Medal was awarded to him, and his regard for the Society has been testified by his making a bequest of Ioool. to our Scientific Relief Fund.

Among mathematicians we have lost Dr. Isaac Todhunter, whose educational treatises have for many years been recognised as standard works, and whose elaborate histories of different branches of mathematical science have carned for him a high reputation ; and $\mathrm{Mr}$. Charles W. Merrifield, who, in addition to achieving distinction by his educational works on arithmetic and mathematics, did much in the direction of the practical application of science, and at the Royal School of Naval Architecture and Marinc Engineering successfully laboured in improving the stability and the sea-going powers of the British Navy.

Another distinguished mathematician whom we have within the last few weeks had the misfortune to lose, was the Rev. Richard Townsend, Professor of Natural Philosophy in the University of Dublin, whose labours in the more abstruse fields of geometrical speculation extended over a period of nearly forty ycars. Mr. James Rennie was also a votary of mathematical research.

Among practical men of science, the veteran Mr. Charles Manby, who for forty-five years had been Secretary or Honorary Secretary of the Institution of Civil Engineers, will deservedly take a high place.

The anatomical and physiological labours of Prof. Allen Thomson had extended over the longer term of fifty-four years, and few possessed the powcr of clearer exposition than he, while for acts of personal kindness there must be many besides myself who owe him a deep debt of gratitude.

Among others connected with the medical profession we miss the distinguished surgeon Mr. Cæsar Hawkins, Dr. Alexander "Tweedie, and Sir Erasmus Wilson, whose name will long survive, not only in connection with dermatology and the Chair of Pathological Anatomy at Aberdeen, but with the Egyptian obelisk, known as Cleopatra's Needlc, the presence of which in London is entircly due to his liberality.

In Mr. R. A. C. Godwin-Austen we have lost one who for nearly fifty ycars had ranked among the foremost of English geologists. His manifold observations will be recorded elsewhere, but as an instance of his critical powers, I may mention his now classical paper on the possible extension of the Coal Measures beneath the south-eastern part of England, read in 1855, his speculations in which as to the western extension of the axis of Artois, all recent deep borings within the Thames Basin have so fully substantiated.

In Dr. Wright we have lost an accomplished palocontologist whose knowledge of the fossil Echinodermata and Ammonitidx was almost unrivalled.

The Duke of Buccleuch had for fifty years been one of our Fellows, and in 1867 occupied the position of President of the British Association; while Sir Bartle Frere, although an ethnologist and geographer, will probably be better lnown as an able and energetic public servant and administrator than as a man of science.

In common with the nation at large, we have to deplore the untimely and unexpected decease of another distinguished states man, the late Postmaster-General, $\mathrm{Mr}$. Fiawcett. $\mathrm{A}$ man of rare mental powers, the effect upon him of the grealest of all physical deprivations, the loss of sight, was only to makc him rise superior to his misfortune. As a student of political economy he attained a high reputation, and he turned his mastery of the subject to good account when he entered into the sphere of public life towards which his natural aspirations led him. His singleness and honesty of purpose, the inhorn justice of his wellbalanced mind, his clevotion to the public good, and his invariable courtesy, endcared him alike to political friends and opponents ; while to those who were brought into more immediate contact with him, his truly sympathetic nature, and the marvellous memory which preserved even minute details of former conversations, gave a charm to his intercourse which none who enjuyed it will ever forget.

As I have already observed, our losses on the home list, including one resignation of Fellowship and one removal from our list, are less than in many former years, being altogether $2 \mathrm{r}$ in number; we have, on the other hand, elected 16 Fellows, including one Privy Councillor. It would, however, appear that our numbers are gradually attaining to something like a state of equilibrium, and that if our elections continue to be limited as at present, the roll of the Society will remain at its present standard of about 470 Fellows. Looking at the recognised longevity of scientific men and the age at which many now achieve the distinction of being elected into the Society, it seems to me not improbable that our numbers will ere long show a tendency to increase rather than to diminish.

Of the Philosophical Transactions three parts, and of the Procedings eleven numbers, have been published; while the number of papers received during the past year was I00, as compared with 103 in the previous year. Of these the most numcrous have been in the departments of electricity and magnetism, though physics and mathematics, chemistry, mineralogy, anatomy, and physiology, botany, and morphology have all had their share.

It is hardly within my province to select any papers that we have published as being the most worthy of mention. The mere fact that they have appeared in the Philosophical Transactions is a sufficient voucher for their value. I may, however, call atten. tion to the report of Captain Abney and Dr. Schuster, our Bakerian Lecturer for the present year, on the total solar eclipse of May I7, 1882, which is the outcome of an expedition towards which a grant of $35 \%$. was made from our Donation Fund. Some of the results were mentioned by Mr. Spottiswoode in his Presidential Address of 1882 , but the value of the details with recrard to the corona, and the success which attended the efforts of the photographers, can only be estimated from an examination of the paper itself. The detailed results obtained by the photographers who accompanied the American expedition to Caroline Island in the South Pacific in order to observe the solar eclipse of May $5,188_{3}$, have not yet been brought before the Society.

In respect to biological studies, our record of the past year, though it does not contain the announcement of any very startling results, gives evidence of fruitful activity along various lines of research.

In Botany, Mr. Gardiner has continued his observations on the important subject of the continuity of protoplasm in vegetable cells, which was referred to in the President's Address of last year; he has also brought forward some interesting results derived from an examination of the changes in the gland-cells of Dionxa, which serve still further to illustrate the identity of the fundamental physiological processes in plants and animals. $\mathrm{Mr}$. Bower has dealt with the morphology of the leaf in certain plants, in a memoir both valuable in itself, and noteworthy because hitherto the study of abstract vegetable morphology has perhaps not obtained in this country the attention which it descrves, and which has bcen given to it in other countries, especially in Germany.

In Physiology two important papers have been presented on the difficult sulject of the functions of the cerebral convolutions, one by Drs. Ferrier and Yeo, and the other by Prof. Schäfer and Mr. Horsley. Both contain observations which demand careful consideration by all physiologists.

The results of the study of animal forms which is happily being carried on with great activity, I may say, all over the United Kingdom, are for various reasons principally recorded elsewhere than in the pares of the Transactions or Proceedings of this Society. Nevertheless, this subject has also been fairly represented at our meetings. Our distinguished and unwearied Fellow, Prof. W. Kitchen Parker, is still continuing his elaborate and valuable rescarches on the vertebrate skull ; and during the past session the Society has had the pleasure of receiving several short papers, expounded in person by their author, from 
a veteran in the study of animal morphology, whose first communication to the Society bears the date of 1832 . I need hardly say I mean Sir Richard Owen.

A few words must be said with regard to the acquisitions made by our library and collections. Our gallery of portraits has, through the lind liberality of Dr. Wilson of Florence, received two important additions in the form of half-length original portraits of the distinguished mathematicians and philosophers, Leibnitz and Viviani, both of whom were Foreign Members of this Society. When we remember the warmth of feeling with which the rival claims of Newton and Leibnitz to the invention of Fluxions or the Differential Calculus were for many years discussed, and call to mind that the question occupied the attention of a Committee of this Society in 1712 , which reported in favour of Newton's claims, we may rejoice that the heat of the controversy is long since over, and congratulate ourselves that the portraits of these rival intellectual giants now hang peacefully side by side on our walls. The portrait of Viviani, the great gcometrician, the pupil of Galileo and the associate of Torricelli, and a contemporary of Newton and Leibnitz, finds also a fitting resting-place in our gallery.

Our portfolio of engraved and lithographic portraits of scientific men has been considerably augmented by liberal donations from the executors of our former President, the late Sir Edward Sabine, through Mr. R. H. Scott.

The Lalande Medal, which had been awarded by the French Academy to Sir Edward in 1826, and which, logether with a Royal Gold Medal, was presented to the Scientific Relief Fund, was by the Council redeemed from the Fund, and will be preserved among our other medals as a memorial of one who for so long a period rendered important services to the Society. A bronze medal of our distinguished Fellow, Prof. Sylvester, has been presented to our collection by the Johns Hopkins University, at Raltimore.

The library itself has during the past year received by donations about 380 complete volumes, besides about 240 pamphlets, and more than 2400 parts of serials; 24 charts have also been presented to it.

With regard to our finances, I may venture to say, as your Treasurer, that I consider them to be in a satisfactory condition, I must now turn to some of the subjects which, during the past year, have occupied the attention of the President and Council, and which in more than one instance have brought them into communication with Her Majesty's Government.

In July of last year a letter from the Treasury was received requesting our opinion as to the desirability of subsidising the Armagh Observatory, the income of which had been materially reduced, owing to recent legislation in Ireland. In reply. to this an answer was sent pointing out the good work that had been done in the Observatory, and the exceptional character of the institution, and recommending it to the favourable consideration of the Government. Unfortunately, however, the loss of income applicable to the maintenance of an Observatory has not been made good, though the Treasury, "having regard to the advice of the Royal Society, and to the diminution in the income of the Observatory," has granted a sum of 2,000\%. in aid of its funds, the annual income derived from which sum is to be applied by trustees to the maintenance and purchase of instruments and apparatus.

Another correspondence with the Treasury as to the bathy. metrical survey of the lakes within the British Isles did not lead to any concession in favour of such a necessary complement to the National Ordnance Survey, though the omission in our maps of all details relating to the depth of our lakes and the contour of their beds, cannot be justified on practical, and much less on scientific grounds.

In May last the Astronomer-Royal brought under our notice the position of this country with respect to the International Bureau des Poids et Mesures, an institution established by what is commonly known as the Metric Convention; and it was resolved that in the opinion of the President and Council it was highly desirable that our country should take part in the International Commission of Weights and Measures, and contribute the sum which our adhesion would entail. A deputation was appointed to bring the subject under the notice of the Lords of the Treasury, and, after some correspondence, the Society was authorised to enter into informal negotiations with the officers of the Bureau, with the happy result that Great Britain was invited to join the Metric Convention, and through her Ambassador at Paris has, I believe, now given in her adhesion to it, and is entitled to all the privileges accorded by the Bureat. The appliances at the command of the Bureau for the verification not only of the standards of the metric system, but of other units of measure, far surpass in scientific accuracy anything that is at present available in this country, and we now enjoy the double advantage of being removed from the state of isolation in which for some years we have stood in regard to the other nations of Europe, and of now being affiliated to an establishment in which the verification of standards has been carried to the highest perfection. At the same time, it is distinctly understood that our adhesion to the Bureau in no way commits the Government of this country to any change of opinion favourable to the adoption of the metric system, but that our entire freedom to retain our own system of weights and measures is absolutely preserved. Whatever may be the advantages of the metric system from a scientific point of view, the question whether a scale of weights, money, and measures, which in its lowest denominations follows a duodecimal rather than a decimal system, is not better adapted for the convenience of daily life, is one that by many is regarded as fairly open to discussion.

Another event of both scientific and national importance has been the meeting of an International Conference on the subject of a Prime Meridian of Longitude. The desirability of a common starting-point from which to reckon degrees of longitude has long been felt among all civilised nations, especially those of a maritime character, and was discussed at some length during the Congress of the International Geodetic Association at Rome in October 1883. It was not, however, until the end of last year that invitations were issued by the United States Govern ment for different countries to send representatives to an International Conference to be held in the city of Washington for the purpose of discussing, and, if possible, fixing upon a meridian proper to be employed as a common zero of longitude and standard of time-reckoning throughout the globe. The letter of invitation addressed to this country was referred to the President and Council of this Society, with a request to advise the Government whether it was advisable in the interests of science to accept the invitation. In reply, an opinion was expressed as to the high importance, both for the interests of science in general, and of our own country in particular, that our Government should be represented at the Conference, and the Treasury at once sanctioned the expense of sending two delegates to Washington. These were Sir Frederick Evans, the late Hydrographer to the Admiralty, and Prof. J. C. Adams. General Strachey, the Chairman of the Meteorological Committee, was also nominated to represent India, and Mr. Fleming to represent the Dominion of Canada. The delegates assembled at Washington in the month of October last, and proceeded to discuss the questions whether a single prime meridian for all countries should be adopted, and if so, through what point on the earth's surface should that meridian be drawn. After long discussion it was eventually resolved that the meridian of Greenwich should be generally adopted, twenty-two ${ }^{1}$ of the nations voting in favour of this measure, and only one, San Domingo, against it. The representatives of France and Brazil abstained from voting. The proposal for the adoption of Greenwich was made by one of the representatives of the United States of America, and was fully discussed. Our own representatives ably supported the proposal, and another of our most distinguished Fellows, Sir William Thomson, who happened to be in America at the time, was courteously invited to attend the meetings of the Conference, and on the request of the President to express his opinions. The arguments adduced in favour of the adoption of Greenwich were such as must commend themselves to all unprejudiced minds. It could hardly be expected that there should be any special spot upon the earth's surface from which longitude would naturally be reckoned, and the whole question, apart from any sentimental or patriotic feelings, is therefore one of the greatest convenience. Were the employment of degrees of longitude as general geographical units entirely unheard-of up to the present time, it would, of course, be a matter of perfect indifference whether the datum was at Greenwich, Paris, the Ferroe Isles, or any other spot. The meridians most in use are those of the two former places, and when we come to consider that, as was pointed out, the shipping tonnage controlled by the Greenwich

I The following nations voted in favour of Greenwich:-Austria, Chili, Colombia, Costa Rica, Great Pritain, Guatemala, Hawai,, Italy, Japan, Liberia, Mexico, Netherlands, Paraguay, Russia, S
Sivitzerland, Turkey, United States, and Venezuela. 
standard of longitude is about $14,000,000$ tons, while that controlled by the longitude of Paris amounts to $1,750,000$ tons only, the preponderance of convenience in favour of the former is placed beyond all dispute. The use of nautical charts constructed from the meridian of Greenwich, and also of the Greenwich Nautical Almanac, is by no means confined to the British Navy, for numerous other nations have availed them. selves of the long-extended labours of our hydrographers, and the computations of our astronomers. At the same time there is no one among us who would for a moment venture to dispute the vast services to science which have been rendered by French astronomers and geographers, nor should we contest the right of French savants to regard Paris as the $\mu \in \sigma o ́ \mu \phi \alpha \lambda o s$ é $\sigma \tau \hat{l}^{\prime} \alpha$ of all other branches of science; the question of a common zero of longitude, however, is not only of scientific but of commercial importance, and we may be confident that eventually our friends on the other side of the Channel, whose metric system has been so largely adopted by other countries, will in their turn sacrifice their own meridian, and adopt that which all neighbouring countries have declared to be the most convenient for general use. If some French locality on the meridian of Greenwich, such for instance as Argentan, were nominally the French datum, the results would be the same so far as maps and charts are concerned, and the natural patriotism of the French nation would remain uninjured.

The adoption of a universal day has also been recommended by the Conference. It is to be a mean solar day to begin for all the world at the moment of mean midnight of the initial meridian, coinciding with the beginning of the civil day and date of that meridian, and is to be counted from zero up to twenty-four hours.

The great volcanic eruption of Krakatoa, in the Straits of Sunda, which took place in August of last year, was followed by remarkable atmospheric and other disturbances, observations on which have been communicated to this and various other learned Societies, and have led to much interesting discussion. The fact, as pointed out by General Strachey and Mr. Scott, that at some barometrical stations the atmospheric wave caused by the eruption was still to be traced until about $\mathbf{I 2 2}$ hours after its origin, and that it must have travelled more than three times round the entire circuit of the earth, shows how vast must have been the initial disturbance causing the wave. The possibility of the remarkable atmospheric appearances which so constantly accompanied the rising and setting of the sun for some month subsequent to the eruption being due to volcanic dust in suspension in the air, offered a farther incentive to investigate the whole history of the eruption. In consequence, the Council in January last nominated a Committee to collect the various accounts of the volcanic cruption at Krakatoa and attendant phenomena, in such form as shall best provide for their preservation and promote their usefulness, and a sum of $100 l$. in all has been granted from the Donation Fund to defray the expenses of the Committee. A Committee of the Royal Meteorological Society, which had already been appointed to study the sunset phenomena of $1883-84$, joined forces with our Committee, and their united labouts, with Mr. A. Ramsay as secretary, have resulted in the accumulation of a voluminous mass of material. The accounts given in the chief British and foreign scientific serials have been extracted and classified, and the times of the various observations reduced to Greenwich mean time.

The literature on the subject, as Mr. Symons informs me, seems almost inexhaustible, and the Committee, feeling that some limit must be adopted, have now stopped the collection of further data, and are engaged in the discussion of what have already been obtained. The manuscript is classified according to strbjects, and each of these is being studied by the members of the Committee most familiar with it. It is to be hoped that in the ensuing session we shall be favoured with some of the results of their labours.

In the Presidential Address of last year mention was made of a series of borings which it was proposed to make across the delta of the Nile in Egypt, and which, with the sanction of the Secretary of State for War, had been intrusted to the officer commanding the Royal Engineers attached to the army of occupation in Egypt. Shortly afterwards a Report from Col. Heriot Maitland, R.E., and Major R. H. Williams, R.E., was received, giving an account of a boring at Kasr-el-Nil, near Cairo, which had been carried to a depth of 45 feet, and of a second boring at Kafr Zaiyat, where a depth of 84 feet was attained. In both cases great difficulties had to be surmounted, but in neither was the solid rock reached beneath the superficial deposits. A second Report from the same officers, dated January is last, states that a third boring had been executed at Tantah, this time by the sappers of the Royal Engineers, and not by Arab workmen, though still with but imperfect tools. In this instance a depth of 73 feet was reached, but again without finding the solid rock. Samples of the materials obtained at different depths in these three borings have been forwarded to the Society by the War Department, and Prof. Judd has kindly undertaken their microscopic examination, and will shortly report the results of his labours to the Committee in charge of the subject.

With regard to the continuance of the borings, which seem to promise information of great value and interest, it is to be feared that the attention of the military authorities will for some time to come be attracted to more urgent business, though the Council of this Society has expressed its willingness to grant from the Donation Fund a further sum of $200 l$., with the view of obtaining better apparatus for boring than that which has hitherto been employed.

The publication of the results of the Challenger Expedition, with which a Committee of this Society is to some extent concerned, has made considerable progress during the past year. Mr. Murray informs me that 47 Reports, forming 13 large quarto volumes, with 6276 pages of letterpress, $105 \mathrm{r}$ lithoyraphic plates, many woodcuts, charts, and other illustrations, have now been published. Nine other Reports are now being printed, and the eleventh Zoological volume and the first Botanical volume will be issued during the present financial year.

The work connected with the remaining thirty-six memoirs is making satisfactory progress, a large instalment of the manuscript being already prepared, and many of the plates either already printed off or drawn on the stone.

There has been an unavoidable delay in the case of the two volumes containing the narrative of the cruise and a general account of the scientific results of the Expedition, but it is expected that they will be issued within the next three months, and possibly before the end of the current year.

It was estimated that the investigations connected with the collections and observations made during the Expedition would be completed and published in I887, and Mr. Murray has every reason to believe that the work will be finished within the estimated time.

The tenth Zoological volume which has just been issued, contains important Reports on the Nudibranchiata, Myzostomida, and Cirripedia, by Drs. Rudolph Bergh, L. von Graff, P. P. C. Hoek, as well as on the Cheilostomata, a sub-order of the Polyzon, by Mr. George Busk. A first instalment of the Anthropological Report is also given by Prof. William Turner, in a detailed examination of the human crania, upwards of 60 in number, brought home by the Expedition. The total number of crania, however, described and tabulated in the memoir is I43, the whole from aboriginal and as yet uncivilised people. The previous Zoological volume is devoted to an exhaustive examination of the Foraminifera, by Mr. H. B. Brady.

The subject of the International Polar Observations, which were carried out during the twelve mnnths ending with August I 883, has been touched on in recent Presidential Addresses, and in that for $188 \mathrm{I}$ the general outline of the whole scheme was indicated. Now, however, the programme then only sketched out has been more than fulfilled, no less than $x_{4}$ stations for observers, 12 for the Northern and 2 for the Southern IIemisphere, having been organised. Of all the expedition", one only, that from Holland, failed to reach its destination, Dickson Harbour, at the mouth of the Obi River, as it was beset by ice in the Kara Sea, in the month of September 1882 . The ship which carried the members of the expedition sank in the month of July $188_{3}$, but they all renched home in safety, having carried out their observations as fully as lay in their power. One of the two expeditions sent out by the Chief Signal Office, Washington, was not so fortunate. The party under I ieutenant Greely, after spending over two years at Lady Franklin Bay, Smith's Sound, was eventually rescued at Cape Sabine, in July last, but not before many of its members had succumbed beneath the fearful hardships of their protracted Arctic sojourn.

The actual points of observation, going eastwards from Behring Straits, and the States which sent out the expeditions, are tabulated below :-

Point Barrow .............. The United States.

Fort Rae ................... Great Britain and Canada. 


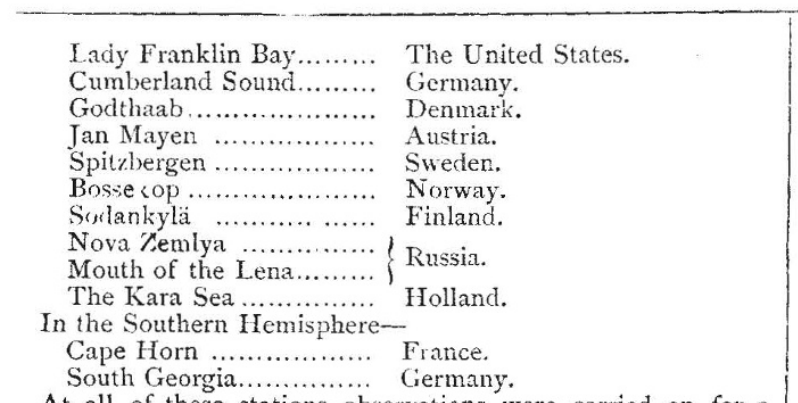

At all of these stations observations were carried on for a year, and at some for even a longer period.

In the month of April last a Conference was held at Vienna, to decide as to the form and mode of discussion and publication of the results, and it may be hoped that these will appear before the end of 1885 .

Of the serial publication, "Communications from the International Polar Commission," six parts, with an aggregate of 334 pages, have already appeared, and in it will be found all particulars of the undertaking.

The regulations under which the Government Grant of 4000 l. is administered have during the past year been again under discussion, and have in some respects been slightly modified. It is, of course, needless to repeat that this grant, though nominally made to the Royal Society, in no way adds to its funds, while its administration rests with a Committee of from sixty or seventy members, many of whom are not of necessity Fellows of our Society. As the grant is now made in two instalments, it has been arranged that the meetings of the Committee shall be held twice in each year, viz., in May and I)ecember, which it is hoped will amply meet the convenience of applicants for grants.

In looking back upon the grants which have been made during the past year, I think that a tendency may be observed on the part of the Committee to devote considerable sums in aid of extensive researches rather than to fritter away the money at their disposal in a series of small grants. They have, for instance, allotted the sum of $500 \mathrm{l}$. towards the exploration of Kilimanjaro and the adjoining mountains of Tropical Africa, and $200 l$. in aid of an expedition for the exploration of the mountain of Roraima in British Guiana. A grant of 200l. has also been made towards a report on the Flora of China; while 300 . has been allotted towards the extra accommodation and instruments for magnetic observations in the new Observatory of the Royal Cornwall Polytechnic Society. It will be remembered that, in his Address last year, the President called attention to the discovery by Dr. Huggins of a method of photographing the solar corona without an eclipse; and, for the purpose of making further experiments in this direction, and for carrying on other physical observations at some place of high elevation and of easy access, a grant of 250 . was placed at the disposal of a Committee. The place of observation selected by the Committee was the Riffel, near Zermatt, in Switzerland, which has an elevation of 8500 feet, and possesses important advantages both of access, and of hotel accommodation. They appointed Mr. C. Ray Woods, who had had experience in photographing the corona during the eclipse of $\mathbf{1 8 8 2}$ in Egypt, and again in Caroline Island in $\mathrm{ISS}_{3}$, to take charge of the work under the instructions of Dr. Huggins and Capt. Abney.

Mr. Woods arrived at the Riffel in the beginning of July, when he erected the necessary instruments under a tent of "Willesdenised" paper, and continued at work there until September 21. Unfortunately, the present year has been exceptionally unfavourable for work on the corona, in consequence of an unusual want of transparency in the higher regions of the atmosphere. This probably may be owing to the presence there of ice-crystals or of small particles of matter of some kind, such as, personally, I am tempted to think might be due to the Krakatoa eruption. Whatever the cause, the sky as seen from the Riffel was far from being so clear as it has been during former years. Mr. Woods observed that the freer the lower air was from cloud and mist, the more distinctly came out a great aureola around the sun, which he found to have a diameter of about $44^{\circ}$, and to be of a faint red near the outer boundary, and bluish-white within, up to the sun's limb.

These unfavourable conditions of the atmosphere bave made it impossible for Dr. Huggins to obtain any photographs of the corona in England. The great advantage at the Riffel of being free from the light scattered from the lower 8000 feet of air has enabled Mr. Woods, notwithstanding the serious drawback of the persistent aureola, to obtain about $\mathbf{r} 50$ photographs, of which more than half are sufficiently good to show the general form, and a smaller number the stronger details of that part of the corona which lies within from $8^{\prime}$ to $12^{\prime}$ of the sun's limb. It would be premature to express any opinion as to the information which may eventually come out from the Riffel plates. They are now being drawn preparatory to a full discussion. In the meantime I may congratulate the Society upon the confirmation of the hope expressed by our President at the last anniversary, "that a new and powerful method of investigation has been placed in the hands of students of solar physics."

Another of the grants made by the Committee has also contributed to important scientific results, as it has enabled $\mathrm{Mr}$. Caldwell to make some important observations on the early stages of the Monotreme ovum, a brief account of which was communicated to the meeting of the British Association for the Advancement of Science at Montreal. A fuller account of the observations, such as is necessary for the adequate appreciation of their importance and bearings, will, I hope, be laid before the Society during the ensuing session, when we shall also probably hear the result of similar investigations in like manner rendered possible by the existence of the Government Grant.

Some slight aid has been rendered from the same source towards the reduction of observations carried on at the meteorological station on the summit of Ben Nevis. This Observatory, situated on the highest point within the United Kingdom, has through the past year been under the charge of Mr. R. T. Omond and two assistants. During the summer months the buildings of the Observatory have been enlarged by the addition of new observing-rooms and increased accommodation for the observers and any scientific workers who may desire to carry on those physical researches for which the climate and position of Ben Nevis afford many' facilities.

The erection and equipment of the Observatory have cost more than 5000l. ; and, in connection with the observations carried on at the top of the mountain, others have been daily made near the sea-level at Fort William. A first report on these conjoint high-and low-level observations, which began in $188 \mathrm{r}$, has been prepared by Mr. Buchan ("Fournal of the Scottish Meteorol. Soc.," 3rd Series, No. I (I884), p. 4). The monthly normals for atmospheric pressure and tewperature have been approximately determined for the Observatory. Important results have also been obtained relating to the decrement of temperature with height, for different 11.onths of the year and hours of tile day, the diurnal variations of the wind's velocity, the very large increase in the rainfall on and near the summit, and the altogether unexpected hygrometric conditions of the air in their relation to the cyclones and anticyclones of North-Western Europe.

Another of the funds at our disposal, the Scientific Relief Fund, requires a few words of mention. Its resources have been considerably enriched during the past year by the legacy of Iooo $\%$ from Sir William Siemens, and nearly $50 l$. from the medals offered by the executors of the late Lady Sabine; and the legacy of 1000 . from the late Mr. Bentham will, it is hoped, ere long be received; but even with these munificent additions the income of the fund will amount to only $250 l$. per annum, while last year the calls upon it amounted, I regret to say, to no less than $450 l$. The incalculable value of such a fund to men of science or their families requiring temporary aid must be apparent to all, and looking at the unfortunate necessity for its existence which the calls upon it prove, I venture to commend it to your support. It will, perhaps, not be out of place here to say a few words with regard to the administration of this fund, the existence of which dates from 1859 , and is in a great degree due to the excrtions of the late Mr. Gassiot. The Council of the Royal Society takes charge of any sums contributed to the fund and invests them, applying the interest in grants for the relicf of such scientific men or their families as may from time to time require or deserve assistance. These grants are, however, made only on the recommendation of a committee of seven members who investigate the cases before them, and applications for relief cannot be entertained except on the recommendation of the President of one of the charfered Societies, viz., the Astronomical, Chemical, Geographical, Geological, Linnean, Royal, and Zoological Societies. Since January 1861 , when the first grant was made, the total number of grants has been eighty-eight, and the total sum distributed $4340 \%$. 
Our Donation Fund has also proved of much service, and several of the applications for comparatively small amounts, which were referred by the Government Grant Committee for the consideration of the Council of the Royal Socicty, were met by grants from this source. This most valuable fund, the annual income of which is now about $400 \%$., has, during the past year, rendered important aid to various scientific objects. From it considerable grants have been made towards obtaining specimens of Hatteria and Apteryx ; for cxpenses incurred on account of the voyage and investigations of the surveying-ship Triton; for collection of materials relating to the Krakatoa eruption; towards the borings in the Delta of Egypt ; and, lastly, in aid of the Marine Biological Association.

The close connection of the future of our fisheries with the advancement of certain branches of zoological science was commented upon by our President in his last Anniversary Address, and $I$ have now to record the foundation of two establishments devoted to marine research. The first of these is the station established at Granton, near Edinburgh, mainly through the energetic labours of Mr. John Murray of the Challenger Fixpedition. It consists of a floating laboratory where physical and biological investigations are carried on, and it is provided with a steam yacht for taking obscrvations at sea and procuring spccimens for examination. Chemical and other laboratories are now being erected on the shore, close to the inclosed piece of water where the floating laboratory is moored. Tiro naturalists, a chemist and a bolanist, are permanently attached to the station, and have an engineer, a fisherman, and three attendants to assist them in conducting regular systematic observations. $2500 /$. have been spent on the equipment of the station, and it has at present an income of 400 l. a-year, independent of tho grants which some of the permanent staff bave reccived from the Government Grant Committee to aid them in their rescarches. It is well that it should bo known that any scientific observer is at liberty to make use of the station free of charge; indeed, during the past year five gentlemen and one lady have availed themselves of this privilege during short periods of time.

But the movement in favour of such stations has not been confined to Scotland, for 1 have also to chronicle the foundation of the Marine Biological Association, which originated in a meeting held in these rooms on March 31 last, our President being in the chair, and many of our principal naturalists taking part in the proceedings. The formation of such an Association has long been hoped for by many interested in obtaining a correct knowlege of the life and conditions of our sea-coast, who are now principally indebted to Prof. Ray Iankester for the realisation of their hopes. The opcrations of the Association will in no way clash with those of the station at Granton, but both institutions will work towards a common end. One effect, indeed, of the new Association will probably be to render all the more fruitful the labours on the more northern shores by instituting similar researches at other parts of the coast of our island.

The work of the Association is as yet in the inceptive stage, but a site well aclapted for a marine observatory will, through the liberal endeavours of the Mayor and Corporation of Plymouth, probably be secured in that town, some citizens of which have also promised a noble donation of $\mathrm{I} 000 \mathrm{l}$. towards its erection. The Clothworkers' Company has contributed 500\% and the Mercers' Company 250 guineas, while the Council of this Society has also shown its sympathy with the movement by a grant of 250l., and the British Association by one of 1502 . Handsome donations have also been made by private individuals, and the number of members of the Association is gradually increasing. When once the station is completed and at work, and its aims and operations become better known, I make little doubt that it will receive a much larger share of public support. But before the station can be erected and at work, it is calculated that an outlay of $\mathrm{I}, 0 \mathrm{col}$. is necessary for its building and equipment, of which as yet not quite half is forthcoming, and 1 venture to take this opportunity of enforcing the claims of the Association upon all who are interested in "the improvement of natural knowledge." As has already been pointed out in the memorandum issued by the Association, "great scientific and practical results have bcen obtained in other countrics, notably in the United States of America, in Germany, France, and Italy, by studies carried on through stch laboratories as the Marine Biological Association proposes to erect in this country," and I may add as is already at worls at Granton. When we consider the enormous importance of our fishcries, and how large may be the amount of waterial benefit derived from a scientific investigation of the causes of their increase and diminution, it will, I think, be evident that the work to be carried on at these stations is not only for such a purpose as the development of abstract biological science, important as that may be, but for the advancement of our national resources. It is, therefore, to be hoped that, in addition to the private support which they will receive, they may in some manner be recognised by the nation at large as centres for carrying out systematic in vestigations into the circumstances determining marine life, from which a portion of our food-supply is drawn, and a much larger portion might probably be derived. The importance of our sea fisheries, which it will be one of the principal objects of the Association to promote, has of late years been more fully recognised, and the recent International Fisheries Exhibition has done much to popularise the subject; while the official appointment of our l'resident also proves that in the opinion of our Government the scientific aspects of our fisheries are not to be neglected.

In the last Presidential Address reference was made to the great desirability of carrying out, on the part of this country, investigations into the nature of cholera in continuation and extension of those so zealously and bravely initiated by the distinguished German inquirer Koch. Although the Society has had no very direct influence in the matter, the Fellows will, I venture to think, regard it as a subject for congratulation that the wish then cxpressed from this chair has been fulfilled, and that the distingnished expert in such questions-our Fellow, Th. Klein - is at present engaged in India in the investigation of cholcra at the instance of the Indian Government. It is sad to think how much nearer our own shores such investigations might have been conducted; may it be long ere they can be instituted on this side of the Channel.

These remarks have already cxtended to such a length that I can now only briefly refer to a few of the events of scientific interest which have during the past year occupied the attention of the Society or of a large number of its Fellows. In the month of April last the University of Edinburgh celebrated its Tercentenary with great pomp and no less hospitality, upwards of $\mathbf{I} 20$ delegates from various universities and other learned bodies being invited as guests. On this occasion Lord Rayleigh kindly consented to be our representative, and was among those on whom the University conferred the hororary degree of LL.D. The same distinguished Fellow occupied the Presidential chair at the meeting of the British $\Lambda$ ssociation for the Advancement of Science at Montreal, on which occarion many of our body took the opportunity of crossing the Atlantic. Owing to the munificent liberality and ungrudering hospitality of our brethren in the Dominion of Canada, the somewhat bold experiment of holding a meeting of the Association beyond the limits of the British Isles has proved a great success, though, perhaps, it is an experiment which would require exceptional conditions to be successfully repeated.

The Society was represented by delegates at the meeting of the American Association for the Advancement of Science at Philadelphia in September last. The Electrical Exhibition at the same place resulted in the formation of a Memorial Library in connection with the Franklin Institute, to which separate copies of the papers relating to electricity that have appeared in the Philosophical Transactions have been granted by the Council. An Electrical Congress at Paris, and an Ornitbological one at Vienna have also been among the events of the year.

Subscribers to the Darwin Memorial Fund will be pleased to bear that a finc block of marble has been secured for the statue to be erceted in the Natural History Museum at South Kensington, and I an glad to learn from Mr. Boehm that his work will probably be completed by the end of this year. When the total cost of the statue has been ascertained, it will be necessary to hold a meeting of the Committee in charge of the Memorial Fund to dctermine the manner in which the balance is to be applied.

It now only remains for me to thank the Fellows and others conversant with the subjects on which I have touched, for information kindly afforded me; to thank yon for the attention with which you have listened to me, and to express a hope that it may not again for many years occur that the Anniversary Address from this Presidential chair shall have to be delivered by deputy.

After the Address the awards of the medals and the election of the Council for the ensuing year were proceeded with; these we 
have already referred to. A gloom was cast over the meeting by the announcement of the sudden death of Prof. Kolbe, the distinguished recipient of the Davy Medal.

The Annual Dinner subsequently took place at Willis's Rooms, the Treasurer being supported by the Lord Chancellor, the Marquess of Salisbury, the Lord Mayor, and others.

\section{THE WAVE THEORY OF LIGHT}

II.

TO continue our study of visible light, that is, undulations extending from red to violet in the spectrum (which I am going to show you presently), I would first point out on this chart that in the section from letter "A " to letter " $D$ " we have visual effect and heating effect only; but no ordinary chemical or photograpbic effect. Photographers can leave their usual sensitive chenically prepared plates exposed to yellow light and red light without experiencing any sensible effect; but when you get

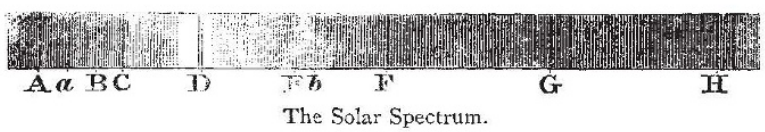

toward the blue end of the spectrum the photographic effect begins to tell, more and more as you get towards the violet end. When you get beyond the violet, there is the invisible light known chiefly by its chemical action. From yellow to violet we have visual effect, heating effect, and chemical effect, all three ; above the violet only chemical and heating effects, and so little of the heating effect that it is scarcely perceptible.

The prismatic spectrum is Newton's discovery of the composition of white light. White light consists of every variety of colour from red to violet. Here, now, we have Newton's prismatic spectrum produced by a prism. I will illustrate little in regard to the nature of colour by putting something before the light which is like coloured glass ; it is coloured gelatine. I will put in a plate of red gelatine which is carefully prepared of chemical materials, and see what that will do. Of all the light passing to it from violet to red it only lets through the red and orange, giving a mixed reddish colour.

Here is another plate of green gelatine. The green absorbs all the red, giving only green. Here is another plate absorbing something from each portion of the spectrum, taking away a great deal of the violet and giving a yellow or orange appearance to the light. Here is another absorbing out the green, leaving red, orange, and a very little faint green, and absorbing out all the violet.

When the spectrum is very carefully produced, far more perfectly than Newton knew how to show it, we have a homogeneous spectrum. It must be noticed that Newton did not understand what we call a homogeneous spectrum; he did not produce it, and does not point out in his writings the conditions for producing it. With an exceedingly fine line of light we can bring it out as in sunlight, like this upper picture, red, orange, yellow, green, blue, indigo, and violet, according to Niewton's nomenclature. Newton never used a narrow beam of light, and so could not have had a homogeneous spectrum.

This is a diagram painted on glass and showing the colours as wc know them. It would take two or three hours if I were to explain the subject of spectrum analysis to-night. We must tear ourselves away from it. I will just read out to you the wave lengths corresponding to the different positions in the sun's spectrum of certain dark lines commonly called "Fraunhofer's lines." I will take as a unit the one-hundred thou-andth of a centimetre. A centimetre is ' 4 of an inch; it is a rather small half an inch. I take the thousandth of a centimetre and the hundredth of that as a unit. At the red end of the spectrum the light in the neighbourhood of that black line " $A$ " has for its wave length 7.6 ; " $B$ " has $6.87 ;$ " $D$ " has 5.89 ; the "frequency" for " $A$ " is 3.9 times roo million million; the frequency of " $D$ " light is 5 . I times 100 million million per second.

Now what force is concerned in those vibrations as compared with sound at the rate of 400 vibrations per second; suppose for a moment the same matter was to move to and fro through

1 A Lecture delivered at the Academy of Music, Philadelphia, under the auspices of the Franklin Institute, September 29, 1884 , by Sir William Thomson, F.R.S., LL.D. (Contintied from p. 94). the same range, but 400 million million times per second. The force required is as the square of the number expressing the frequency. Double frequency would require quadruple force for the vibration of the same body. Suppose I vibrate my hand again, as I did before. If I move it once per second a moderate force is required ; for it to vibrate ten times per second roo times as much force is required ; for 400 vibrations per second 160,000 times as much force.

If I move my hand once per second through a space of a quarter of an inch a very small force is required; it would require very considerable force to move it ten times a second, even through so small a range; but think of the force required to move a tuning fork 400 times a second; compare that with the force required for a motion of 400 million million times a second. If the mass moved is the same, and the range of motion is the same, then the force would be one million million million million times as great as the force required to move the prongs of the tuning fork. It is as easy to understand that number as any number like 2,3 , or 4 .

Consider gravely what that number means and what we are to infer from it. What force is there in space between my eye and that light? What forces are there in spacs between our eyes and the sun, and our eyes and the remotest visible star? There is matter and there is motion, but what magnitude of force may there be?

I move through this "luminiferous ether" as if it were nothing. But were there vibrations with such frequency in a mediuin of steel or brass, they would be measured by millions and millions and millions of tons action on a square inch of matter. There are no such forces in our air. Comets make a disturbance in the air, and perhaps the luminiferous ether is split up by the motion of a comet through it. So when we explain the nature of electricity, we explain it by a motion of the luminiferous ether. We cannot say that it is electricity. What can this luminiferous ether be? It is something that the planets move through with the greatest ease. It permeates our air; it is nearly in the same condition, so far as our means of judging are concerned, in our air and in the inter-planetary space. The air disturbs it but little ; you may reduce air by air-pumps to the hundred-thousardth of its density, and you make little effect in the transmission of light through it. The luminiferous ether is an elastic solid. The nearest analogy I can give you is this jelly which you see. ${ }^{1}$ The nearest analogy to the waves of light is the motion, which you can imagine, of this elastic jelly, with a ball of wood floating in the middle of it. Look there, when with my hand I vibrate the little red ball up and down, or when I turn it quickly round the vertical diameter, alternately in opposite directions; - That is the nearest representation I can give you of the vibrations of luminiferous ether.

Another illustration is Scottish shoemaker's wax or Burgundy pitch, but I know Scottish shoemaker's wax better. It is heavier than water, and absolutely answers my purpose. I take a large slab of the wax, place it in a glass jar filled with water, place a number of corks on the lower side and bullets on the upper side. It is brittle like the Trinidad pitch or Burgundy pitch which I have in my hand. You can see how hard it is, but if left to itself it flows like a fluid. The shoemaker's wax breaks with a brittle fracture, but it is viscous and gradually yields.

What we know of the luminiferous ether is that it has the rigidity of a solid and gradually yields. Whether or not it is brittle and cracks we cannot yct tell, but I believe the discoveries in electricity, and the motions of comets, and the marvellous spurts of light from them, tend to show cracks in the luminiferous ethershow a correspondence between the electric flash and the aurora borealis and cracks in the luminiferous ether. Do not take this as an assertion, it is hardly more than a vague scientific dream : but you may regard the existence of the luminiferous ether as a reality of science, that is, we have an all-pervading medium, an elastic solid, with a great degree of rigidity; its rigidity is so prodigious in proportion to its density that the vibrations of light in it have the frequencies I have mentiond, with the wave lengths I have mentioned.

The fundamental question as to whether or not luminiferous ether has gravity has not been answered. We have no knowledge that the luminiferous ether is attracted by gravity; it is sometimes called imponderable because some people vainly imagine that it has no weight. I call it matter with the same kind of rigidity that this elastic jelly has.

' Exhibiting a large bowl of clear jelly with a small red wooden bal embedded in the surface near the centre. 